\title{
Analysis of the Methylome of Human Embryonic Stem Cells Employing Methylated DNA Immunoprecipitation Coupled to Next-Generation Sequencing
}

\section{Christina Grimm and James Adjaye}

\begin{abstract}
The analysis of DNA-methylation on a genome-wide scale by next-generation sequencing techniques is an invaluable tool towards the understanding of the epigenetic basis of cellular differentiation. Methylated DNA immunoprecipitation (MeDIP) is an immunocapturing method using an antibody targeting 5-methylcytidine $(5 \mathrm{mC})$ and thereby enriching methylated DNA. MeDIP combined with next-generation sequencing (MeDIP-seq) provides a powerful tool for the analysis of genome-wide DNA-methylation profiles. Here, we describe a protocol for the preparation of MeDIP samples suitable for next-generation sequencing on a Genome Analyser (Illumina).
\end{abstract}

Key words: Epigenetic, DNA-methylation, MeDIP, 5-mCytosine

\section{Introduction}

Methylation of Cytosine at the carbon-5-position of the pyrimidine ring to generate 5 -methylcytosine $(5 \mathrm{mC})$ is an epigenetic modification present in most eukaryotic organisms and is catalysed by DNA methyltransferases (DNMT). In mammals, methylation occurs preferentially at $\mathrm{CpG}$ sites, although in human embryonic stem cells about a quarter of all methylation is detected in a non-CpG context (1). The human (mouse) haploid genomes harbour about 28 (21) million CpGs and according to the definition used by UCSC, 28.691 or 16.026, CpG islands were detected in the hgl9 version of the human or $\mathrm{mm} 9$ version of the mouse genome, respectively (http://genome.ucsc.edu). Recently, another cytosine modification was identified: 5-hydroxy-methylcytosine, $5 \mathrm{hmC} \mathrm{(2),}$ its occurrence is dependent on the cell type analysed. For example, 
it occurs within 0.01 (HeLa or HEK293FT) to 0.4\% (adult mouse cerebellum) of all nucleotides (3).

Since DNA-methylation is not maintained during PCR amplification, amplification steps prior to bisulfite (BS)-conversion, restriction digest, or enrichment are not possible. The available techniques for the analysis of methylated cytosines can be grouped into three main classes, viz:

1. BS-based techniques where the DNA is treated with BS leading to a conversion of unmethylated cytosine to uracil while leaving methylated cytosines intact. During a subsequent PCR amplification step uracil is then replaced by thymine. Sequencing of BS converted DNA (MethylC-seq) (1) requires the resequencing of the whole genome and it is very costly when applied to mammalian genomes. Reduced representation bisulfite sequencing (RRBS) reduces the complexity of the genome by an initial restriction digest of the genomic DNA followed by a size-selection, thereby minimising costs, but also the number of CpG sites analysed (4). The same holds true for an arraybased enrichment of genomic regions prior to BS-treatment and sequencing.

2. Restriction enzyme-based approaches using methylation sensitive restriction enzymes (MRE-seq) which selects for nonmethylated DNA (5), methylation-specific restriction enzymes (e.g., $\operatorname{Mcr} B C)$ or methylation sensitive and insensitive isochizomeres (e.g., HpaII and MspI).

3. Enrichment-based methods using a methylated DNA binding domain (MBD-seq) (5-7) or an antibody against 5-methylcytidine (MeDIP-seq) for the enrichment of methylated sequences $(5,7-11)$. Of these three techniques, only the BS-based techniques provide a base-wise resolution though at a high cost. The restriction enzyme-based techniques are restricted to the recognition sites of the enzymes used, e.g., for MspI about 1.5 million $\mathrm{CpG}$ sites of the 21 million CpGs in the mouse genome are localised in an MspI site. The enrichment-based methods MeDIP-seq and MBD-seq do identify methylated fragments but cannot assess the methylation status of individual CpGs within the fragment as it is achieved by BS-based techniques. However, these techniques provide a good compromise between resolution and cost for the genome-wide analysis of DNAmethylation profiles. In addition, the BS-based methods do not discriminate between $5 \mathrm{mC}$ and $5 \mathrm{hmC}$, whereas the two enrichment-based methods are specific to $5 \mathrm{mC}$ and do not detect $5 \mathrm{hmC}(12)$. A commercial antibody targeting $5 \mathrm{hmC}$ became recently available. Recent comparisons of BS and enrichmentbased methods coupled with next-generation sequencing concluded that all techniques produce accurate methylation data, although differing in their ability to detect differentially methylated regions $(5,7)$. 
Here, we describe MeDIP-seq: methylated DNA immunoprecipitation (MeDIP) is an immunocapturing approach whereby genomic DNA is fragmented, denatured and immunoprecipitated by a monoclonal antibody targeting $5^{\prime}$ methylcytidine and was first applied by Weber et al. (13). When combined with next-generation sequencing (Fig. 1), we prepare the library between the DNAfragmentation and the immunoprecipitation step since T4 DNA ligase prefers double-stranded DNA as a template, the risk of introducing contaminations which will be amplified during the PCR amplification step is minimised and if desired, it is possible to introduce methylated and unmethylated spike-in DNAs as controls for MeDIP-efficiency. A set of lambda-DNA controls is described in ref. 14. Although most published protocols $(5,7,8$, $10,11,14)$ prepare the library before MeDIP, one protocol prepares a second strand synthesis and the library preparation after the immunoprecipitation (9). We successfully applied the MeDIPseq protocol presented here to unveil methylation changes accompanying the differentiation of human embryonic stem cells into endoderm derivatives (11).

Shearing of DNA
Quality controls:
Check fragment size by gel electrophoresis
Quantification by Nanodrop
Library preparation
End repair
'A' tailing
Adapter ligation
Quality controls:
Quantification by Qubit
Test adapter ligation by gel electrophoresis
MeDIP
Quality controls:
Quantification by Qubit
Check enrichment of methylated DNA by qPCR
Library amplification and size selection
Quality controls:
Quantification by Qubit
Check enrichment of methylated DNA by qPCR

Fig. 1. MeDIP-seq experiment. The different experimental steps and quality controls are shown. Library preparation is performed before MeDIP since the DNA is denatured during the experiment and T4 ligase preferentially ligates double-stranded DNA. The size evaluation steps can also be analysed using a Bioanalyser (Agilent) instead of gel electrophoresis. 


\section{Materials}

2.1. General

2.2. Shearing of Genomic DNA

2.3. Library

2.3.1. End Repair

2.3.2. A-tailing

2.3.3. Adapter Ligation

2.4. Methylated DNA Immunoprecipitation
1. 1.5 and $2 \mathrm{ml}$ low-binding DNA tubes (Eppendorf) for library preparation and MeDIP (see Note 1).

2. QIAquick Gel Extraktion Kit (Qiagen).

3. Collection tubes (Qiagen) or $2 \mathrm{ml}$ tubes with the lids cut.

1. Hielscher UTR2000 sonicator with continuous waterbath cooling. Other devices may also be used, e.g., BioRuptor (Diagenode), Covaris, Branson.

2. Orange dye (Sigma-Aldrich) used as tracking dye in the loading buffer (see Note 2).

1. T4 polynucleotide kinase, $10 \mathrm{U} / \mu \mathrm{l}(\mathrm{NEB})$.

2. T4 DNA polymerase, $3 \mathrm{U} / \mu \mathrm{l}(\mathrm{NEB})$.

3. Polymerase I, large (Klenow) Fragment, $5 \mathrm{U} / \mu \mathrm{l}$ (NEB).

4. T4 DNA ligase reaction buffer $10 \times(\mathrm{NEB})$.

5. $25 \mathrm{mM}$ dNTP Mix (GE Healthcare).

1. Klenow Fragment $\left(3^{\prime} \rightarrow 5^{\prime}\right.$ exo- $), 5 \mathrm{U} / \mu \mathrm{l}(\mathrm{NEB})$ with buffer NEB2.

2. $1 \mathrm{mM}$ dATP (GE Healthcare).

3. MinElute PCR Purification Kit (Qiagen).

1. Adapters included in the Genomic Adapter oligo mix for singlereads or paired-reads (Illumina).

2. Quick Ligation Kit (NEB) containing Quick T4 DNA Ligase and Quick Ligation Reaction Buffer $(2 \times)$.

1. 5-Methylcytidine antibody, mouse monoclonal (Eurogentec, \#BI-MECY-1000). A 5-methylcytidine antibody supplied by Diagenode works comparably well. Aliquot the antibody and store at $-20^{\circ} \mathrm{C}$, avoid freeze-thaw cycles.

2. Dynabeads M-280 Sheep anti-Mouse IgG (Invitrogen).

3. Albumin, bovine serum, Fraction V, and BSA (Sigma-Aldrich).

4. $0.5 \% \mathrm{BSA} / \mathrm{PBS}(w / v)$.

5. Magnetic rack for collecting the magnetic beads.

6. $100 \mathrm{mM}$ sodium phosphate, buffer solution $\mathrm{pH} 7.0$ for HPCE (Sigma-Aldrich).

7. $5 \mathrm{M} \mathrm{NaCl}$.

8. Triton X-100 (Sigma-Aldrich).

9. $2 \times$ Immunoprecipitation buffer $(280 \mathrm{mM} \mathrm{NaCl}, 20 \mathrm{mM}$ sodium phosphate buffer $\mathrm{pH} 7.0,0.5 \%$ Triton X-100). 


\subsection{Amplification and Size Selection}

\subsection{Quantitative PCRs for Control of MeDIP Enrichment}

2.7. Quantification
of the DNA

10. SDS elution buffer ( $50 \mathrm{mM}$ Tris- $\mathrm{HCl}, \mathrm{pH} 8.0 ; 10 \mathrm{mM}$ EDTA, $\mathrm{pH} 8.0 ; 1 \%$ SDS $)$.

11. Proteinase $\mathrm{K}$ (Roche Applied Science), dissolve in $\mathrm{H}_{2} \mathrm{O}$ to $20 \mathrm{mg} / \mathrm{ml}$, aliquot, and store at $-20^{\circ} \mathrm{C}$, do not refreeze a thawed proteinase $\mathrm{K}$ aliquot.

12. $1 \times$ TE (10 mM Tris-HCl, pH 8.0, 1 mM EDTA).

13. $2 \mathrm{ml}$ Phase Lock Gel Heavy tubes (VWR International GmbH).

14. Phenol:CHCl3:Isoamyl alcohol, 25:24:1 (Sigma-Aldrich).

15. Polyacryl carrier (Molecular Research Center Inc., Fermentas).

16. 10 mM Tris-HCl, $\mathrm{pH} 8.5$.

1. Primers included in the Genomic Adapter oligo mix for singlereads or paired-reads (Illumina).

2. Phusion High-Fidelity PCR Master Mix with HF Buffer (NEB).

3. $0.2 \mathrm{ml}$ thin-walled PCR tubes.

4. Ultra low range agarose (BioRad).

5. Clean scalpels for excision of the gel fragment.

1. SYBR Green PCR Master Mix (Applied Biosystems).

2. Oligonucleotides for the amplification of a methylated and an unmethylated control region (Table 1).

1. Nanodrop spectrophotometer (Nanodrop).

2. Quant-iT ssDNA kit (Invitrogen) for quantification after MeDIP.

3. Quant-iT dsHSDNA kit (Invitrogen) for quantification of the size selected amplified library.

\section{Table 1}

\section{PCR primers used for evaluating the enrichment of methylated fragments}

\begin{tabular}{llllll} 
Name & Forward primer & Reverse primer & species & Methylated & Reference \\
\hline 4994 & $\begin{array}{c}\text { GGGAATATAAG } \\
\text { GAGCGCACA }\end{array}$ & $\begin{array}{c}\text { TCGGTTAAAAC } \\
\text { GGTCAGGTC }\end{array}$ & Human & + & Butcher and Beck (14) \\
8804 & $\begin{array}{c}\text { CGAGGCGTGA } \\
\text { GTTATTCCTG }\end{array}$ & $\begin{array}{c}\text { CTCTTGTGGCT } \\
\text { GAGCTCCTT }\end{array}$ & Human & - & Butcher and Beck (14) \\
Xist & $\begin{array}{c}\text { CGCGGATCAG } \\
\text { TTAAAGGCGT }\end{array}$ & $\begin{array}{c}\text { AACCACGGAAGA } \\
\text { ACCGCAC }\end{array}$ & Mouse & + & Weber et al. (13) \\
Csa & $\begin{array}{c}\text { TGGTTGGCATTTT } \\
\text { ATCCCTAGAAC }\end{array}$ & $\begin{array}{c}\text { GCACATGGCAA } \\
\text { CTGAAACA }\end{array}$ & Mouse & - & Weber et al. (13) \\
\hline
\end{tabular}


4. QUBIT device (Invitrogen) for quantification using the Quant-it kits.

5. $0.5 \mathrm{ml}$ reaction tubes suitable for the use with a Qubit device (e.g., Axygen PCT-05C, VWR \# Q10212).

\section{Methods}

\subsection{DNA Isolation}

\subsection{Fragmentation of DNA}

DNA isolated by a standard procedure is suitable [phenol-chloroform, or using commercially available kits, e.g., AllPrep DNA/RNA Mini Kit (Qiagen)]. However, it is recommended not to change the DNA isolation method within an experiment. The DNA has to be RNAse free (see Note 3 ). If RNA digestion was not performed during the DNA isolation step, then perform RNAse digest prior to shearing by incubating $1 \mu \mathrm{l}$ of RNase $(10 \mathrm{U} / \mu \mathrm{l})$ with $4-10 \mu \mathrm{g}$ of DNA in a $50 \mu \mathrm{l}$ volume for $1 \mathrm{~h}$ at $37^{\circ} \mathrm{C}$.

DNA is sheared to fragment sizes of 100-400 bp. We use a Hielscher UTR2000 sonifier with continuous water bath cooling set to an amplitude of 1,000 and a duty cycle of 0.5 . 4-8 $\mu \mathrm{g}$ of DNA is sheared four times for $30 \mathrm{~min}$ in $50 \mu \mathrm{l}$ of $10 \mathrm{mM}$ Tris- $\mathrm{HCl} \mathrm{pH} 8.5$ (or in TE) in a $0.5 \mathrm{ml}$ reaction tube. After each $30 \mathrm{~min}$ sonication cycle, vortex the DNA and spin down the contents to collect any droplets that may have formed during sonication (see Note 4).

After sonication, $100 \mathrm{ng}$ of the fragmented DNA is subjected to gel electrophoresis on a $2 \%$ agarose / $1 \times$ TAE gel (Fig. $2 \mathrm{a})$. If the DNA is not sheared sufficiently, shear for an additional $30 \mathrm{~min}$ (see Note 5). Other shearing devices may also be used [e.g., Bioruptor (Diagenode), Covaris]. Conditions need to be adjusted for each shearing device. After sonification, the sheared DNA is purified using Qiaquick columns (up to $10 \mathrm{mg}$ DNA can be purified using one column).
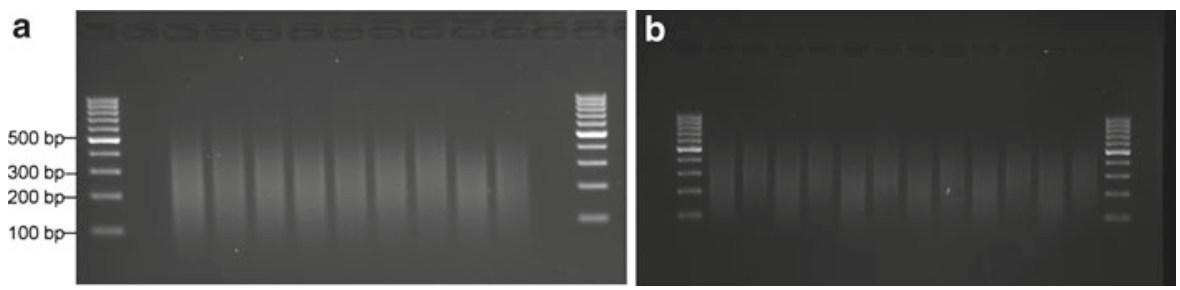

Fig. 2. Size distribution of sheared DNA (a) and of sequencing libraries prior to MeDIP (b). $160 \mathrm{ng}$ of sheared DNA was separated on a $2 \%$ agarose $/ 1 \times$ TAE gel stained with ethidium bromide. The size range of most fragments is between 100 and $400 \mathrm{bp}$ with a mean fragment size of $200 \mathrm{bp}$ (a). To monitor library preparation $100 \mathrm{ng}$ of sheared DNA and sequencing library produced from the same DNA were loaded side by side on a $2 \%$ agarose $/ 1 \times$ TAE gel. The size of the library increases by the size of the ligated adapter sequences (approx. 70 bp) (b). Marker: Gene Ruler 100 bp DNA ladder (Fermentas). If the amount of DNA is low, $50 \mathrm{ng}$ of DNA is sufficient for size evaluation by gel electrophoresis. 
3.2.1. Purification Using Qiaquick Columns
1. Add four volumes QG buffer to your sample (i.e. $50 \mu \mathrm{l} \mathrm{DNA}$ sample, add $200 \mu \mathrm{l}$ QG) and mix by vortexing.

2. Incubate for $3 \mathrm{~min}$.

3. Add 1.3 volumes isopropanol (i.e. $50 \mu \mathrm{l}$ DNA-sample, add $65 \mu \mathrm{l}$ of isopropanol) and vortex.

4. Transfer the solution to a Qiaquick column.

5. Centrifuge $1 \mathrm{~min}$ at $>10,000 \times \mathfrak{g}$.

6. Change collection tube.

7. Aspirate the QG from the inner plastic rim of the column.

8. Pipette $700 \mu \mathrm{l} \mathrm{PE}$ to the column and also to the lid and the outer rim of the column to remove all remaining QG since QG may inhibit subsequent enzymatic reactions.

9. Centrifuge $1 \mathrm{~min}$ at $>10,000 \times \mathfrak{g}$.

10. Change collection tube.

11. Repeat steps 8-10.

12. Centrifuge $1 \mathrm{~min}$ at $>10,000 \times g$.

13. Change collection tube.

14. Aspirate the remaining PE from the inner rim of the column (ca. $2 \mu \mathrm{l}$ ).

15. Centrifuge for $2 \mathrm{~min}$ at $>10,000 \times g$.

16. Change collection tube.

17. Pipette $16 \mu \mathrm{l}$ EB-buffer ( $10 \mathrm{mM}$ Tris- $\mathrm{HCl} \mathrm{pH} 8.5$ ) to the membrane.

18. Incubate $5 \mathrm{~min}$.

19. Centrifuge $1 \mathrm{~min}$ at $>10,000 \times \mathrm{g}$.

20. Pipette $16 \mu \mathrm{l} \mathrm{EB}$ to the membrane.

21. Centrifuge for $2 \mathrm{~min}$.

22. $30 \mu \mathrm{l}$ of DNA will be obtained, since the dead volume of the column is approximately $2 \mu \mathrm{l}$.

Snap freeze your sheared DNA in liquid nitrogen and store at $-20^{\circ} \mathrm{C}$ or proceed with the library preparation (see Note 6 ).

3.3. Library

Library preparation follows in principle the protocol suggested by Illumina with some adjustments as described in http://molbiol. $\mathrm{ru} /$ wiki/Next-generation_sequencing and applied in ref. 11. The Web site was set up by the sequencing group from our department and contains useful protocols and tips on second-generation sequencing. Use low-DNA-binding reaction tubes for the library preparation and the immunoprecipitation (see Note 6). After library preparation, $100 \mathrm{ng}$ of the library and $100 \mathrm{ng}$ of the sheared DNA may be separated on a $2 \%$ agarose $/ 1 \times$ TAE gel in order to analyse the quality of the library. The size of the library should be shifted by the length of the ligated adapters (approx. 70 bp, Fig. 2b). 
1. Set up a $20^{\circ} \mathrm{C}$ water bath.

2. Set up for one reaction:

\begin{tabular}{ll}
\hline $50 \mu \mathrm{l}$ & DNA $(5 \mu \mathrm{g})$ \\
\hline $31.7 \mu \mathrm{l}$ & $10 \times \mathrm{T} 4$ DNA ligase buffer \\
\hline $12 \mu \mathrm{l}$ & T4 DNA polymerase $(3 \mathrm{U} / \mu \mathrm{l})$ \\
\hline $12 \mu \mathrm{l}$ & T4 polynucleotide kinase $(10 \mathrm{U} / \mu \mathrm{l})$ \\
\hline $2.4 \mu \mathrm{l}$ & Polymerase I, large (Klenow) Fragment $(5 \mathrm{U} / \mu \mathrm{l})$ \\
\hline $3.2 \mu \mathrm{l}$ & dNTP Mix $(25 \mathrm{mM})$ \\
\hline $205.7 \mu \mathrm{l}$ & $\mathrm{H}_{2} \mathrm{O}$ \\
\hline $317 \mu l$ & Total volume \\
\hline
\end{tabular}

Incubate for $30 \mathrm{~min}$ in a $20^{\circ} \mathrm{C}$ water bath.

Purify using Qiaquick columns and buffer QG

1. Pipette $1,270 \mu \mathrm{l} \mathrm{QG}$ in a $2 \mathrm{ml}$ reaction tube.

2. Add end-repair DNA reaction mix.

3 . Incubate $3 \mathrm{~min}$.

4. Add $412 \mu \mathrm{l}$ isopropanol.

5. Follow the Qiaquick protocol.

6. Elute in $34 \mu \mathrm{l}$ (twice with $18 \mu \mathrm{l}$ of $10 \mathrm{mM}$ Tris- $\mathrm{HCl} \mathrm{pH} 8.5$ ).

1. Set up a $37^{\circ} \mathrm{C}$ water bath.

2. Set up for one reaction:

\begin{tabular}{ll}
\hline $34 \mu \mathrm{l}$ & End-repaired DNA \\
\hline $8.8 \mu \mathrm{l}$ & NEB2 reaction buffer $(10 \times)$ \\
\hline $17.6 \mu \mathrm{l}$ & $1 \mathrm{mM}$ dATP \\
\hline $7.3 \mu \mathrm{l}$ & Klenow Fragment $3^{\prime} \rightarrow 5^{\prime}$ exo- $(5 \mathrm{U} / \mu \mathrm{l})$ \\
\hline $20.3 \mu \mathrm{l}$ & $\mathrm{H}_{2} \mathrm{O}$ \\
\hline $88 \mu \mathrm{l}$ & Total volume \\
\hline
\end{tabular}

Incubate for $30 \mathrm{~min}$ in a $37^{\circ} \mathrm{C}$ water bath.

Purify using Qiaquick MinElute columns and buffer QG.

1. Add $352 \mu \mathrm{l} \mathrm{QG}$.

2. Incubate for $3 \mathrm{~min}$.

3. Add $114 \mu \mathrm{l}$ of isopropanol.

4. Follow the Qiaquick protocol.

5. Elute in $10 \mu \mathrm{l}$ (twice with $6 \mu \mathrm{l}$ of $10 \mathrm{mM}$ Tris- $\mathrm{HCl} \mathrm{pH} 8.5$ ). 
1. Set up a $20^{\circ} \mathrm{C}$ water bath.

2. Add a tenfold molar excess of adapter-oligomix to the $10 \mu \mathrm{l}$ A-tailed DNA fragments. For $5 \mu \mathrm{g}$ of DNA with a mean fragment size of $200 \mathrm{bp}$, add $29 \mu \mathrm{l}$ of adapter oligo mix.

3. Mix gently by pipetting and incubate for $5 \mathrm{~min}$ at RT.

4. Set up a ligase master mix, per reaction:

\begin{tabular}{ll}
\hline $49 \mu \mathrm{l}$ & $2 \times$ Quick ligase buffer \\
$10 \mu \mathrm{l}$ & Quick T4 DNA ligase \\
\hline $59 \mu \mathrm{l}$ & Total volume \\
\hline
\end{tabular}

5. Add $59 \mu \mathrm{l}$ of ligase master mix to the DNA-adapter-mix and mix gently by pipetting up and down.

6. Incubate for $15 \mathrm{~min}$ in a $20^{\circ} \mathrm{C}$ water bath. Purify using Qiaquick columns and buffer QG:

1. Add $392 \mu \mathrm{l}$ QG.

2. Incubate for $3 \mathrm{~min}$.

3. Add $127.4 \mu \mathrm{l}$ of isopropanol.

4. Follow the Qiaquick protocol.

5. Elute in $30 \mu \mathrm{l}(2 \times 16 \mu \mathrm{l} 10 \mathrm{mM}$ Tris- $\mathrm{HCl} \mathrm{pH} 8.5)$.

6. Quantify the concentration using a Nanodrop.

\subsection{Methylated DNA Immunoprecipitation}

3.4.1. Blocking and Coupling the Antibody to the Magnetic Beads
Use $4^{\circ} \mathrm{C}$ cold solutions.

1. Pipette $700 \mu \mathrm{l} 0.5 \% \mathrm{BSA} / \mathrm{l} \times \mathrm{PBS}$ in a $1.5 \mathrm{ml}$ microcentrifuge tube. Prepare one tube per MeDIP-reaction.

2. Vortex the magnetic beads very well.

3. Add $40 \mu \mathrm{l}$ of the magnetic beads to the tube with $0.5 \% \mathrm{BSA} / \mathrm{l} \times$ PBS and mix by inverting the tube gently several times (see Note 7).

4. Collect the magnetic beads using a magnetic rack. After the beads are trapped at the side, invert the magnetic rack to clean the lid of the tube. Aspirate and discard the supernatant.

5. Remove the magnet from the magnetic stand (or take the tube out of the magnetic stand).

6. Resuspend the magnetic beads in $700 \mu$ of $0.5 \% \mathrm{BSA} / \mathrm{l} \times \mathrm{PBS}$ by inverting the tube several times.

7. Repeat steps $4-6$.

8. Repeat steps $4-5$ one more time.

9. Resuspend magnetic beads in $250 \mu \mathrm{l}$ of $1 \times$ IP-buffer by inverting the tube several times.

10. Add $10 \mu \mathrm{l}$ of $5 \mathrm{mC}$-antibody ( $10 \mu \mathrm{g}$, see Note 8 ). 
3.4.2. Methylated DNA Immunoprecipitation
11. Incubate overnight with over head rotating at $4^{\circ} \mathrm{C}$.

12. The next day collect the magnetic beads using a magnetic rack. After the beads are trapped, invert the magnetic rack to clean the lid. Discard supernatant.

13. Resuspend the beads in $1 \mathrm{ml} 0.5 \% \mathrm{BSA} / \mathrm{l} \times \mathrm{PBS}$ by inverting the tube several times.

14. Collect the magnetic beads using a magnetic rack, invert the magnetic rack to clean the lid. Discard supernatant.

15. Repeat steps 13 and 14 one more time.

16. Resuspend the beads in $1 \mathrm{ml} \mathrm{l} \times$ IP-buffer by inverting the tubes several times.

17. Collect the magnetic beads using a magnetic rack, invert the magnetic rack to clean the lid. Discard supernatant.

18. Resuspend the beads in $170 \mu \mathrm{l} \times \mathrm{IP}$-buffer and place on ice until adding the DNA.

1. Dilute $4.2-4.5 \mu \mathrm{g}$ of the library to $133 \mathrm{ng} / \mu \mathrm{l}$ in $10 \mathrm{mM}$ Tris $-\mathrm{HCl}$ $\mathrm{pH} 8.5$.

2. Denature library in thin-walled PCR-tubes for 1 min at $95^{\circ} \mathrm{C}$ in a PCR machine.

3. Immediately place on ice-water and let sit for $3-5 \min$ (see Note 9).

4. Pipette $30 \mu \mathrm{l}$ library and $30 \mu \mathrm{l}$ ice cold $2 \times$ IP to the magnetic beads in $170 \mu \mathrm{l}$ of $\mathrm{l} \times \mathrm{IP}$-buffer from step 18 .

5 . Incubate for $4 \mathrm{~h}$ at $4^{\circ} \mathrm{C}$ with over head rotation.

6. Trap the magnetic beads in a magnetic stand and invert the magnetic rack to clean the lid. Discard supernatant.

7. Add $1 \mathrm{ml}$ of ice cold $1 \times$ IP-buffer and resuspend the beads by inverting the tubes several times.

8. Repeat the washing (steps 6 and 7) two more times.

9. After the last washing step, centrifuge for $3 \mathrm{~min}$ at $960 \times \mathrm{g}$ at $4{ }^{\circ} \mathrm{C}$. Remove any residual liquid. Be careful not to disturb the beads.

10. Add $210 \mu \mathrm{l}$ of SDS elution buffer at RT.

11. Incubate for $15 \mathrm{~min}$ at $65^{\circ} \mathrm{C}$ with briefly vortexing every $2 \mathrm{~min}$. Briefly spin the contents of the tube down.

12. Trap the magnetic beads in a magnetic stand. Pipette the supernatant in a new $1.5 \mathrm{ml}$ tube. Keep the supernatant! It contains the immunoprecipitated DNA.

13. Take the tubes containing the beads out of the magnetic stand. Resuspend the beads in $200 \mu \mathrm{l}$ TE by vortexing. Shortly spin 
3.4.3. Phenol- $\mathrm{CHCl}_{3}$ Extraction 3.5. Quantitative PCR
as Quality Controls the contents of the tube down and collect the beads with the magnetic rack.

14. Combine the supernatant with the first eluate.

15. Add $4 \mu \mathrm{l}$ of proteinase $\mathrm{K}(20 \mathrm{mg} / \mathrm{ml})$.

16. Incubate for $2 \mathrm{~h}$ at $55^{\circ} \mathrm{C}$.

1. Centrifuge a $2 \mathrm{ml}$ PhaseLock tube for $1 \mathrm{~min}$ at $160,000 \times g$ at RT.

2. Pipette the sample $(400 \mu \mathrm{l})$ to the PhaseLock tube, add $400 \mu \mathrm{l}$ phenol:chloroform:isoamyl alcohol, mix vigorously by shaking the tube (do not vortex).

3 . Centrifuge $5 \mathrm{~min}$, at $160,000 \times g$, RT. The organic phase (phenol) and the aqueous (upper) phase (DNA) are separated by a solid phase.

4. Repeat extraction $2 \times$ with $400 \mu \mathrm{CHCl}_{3}$.

5. Pipette the upper phase (aqueous phase containing the DNA) into a $1.5 \mathrm{ml}$ tube containing $16 \mu \mathrm{l}$ of $5 \mathrm{M} \mathrm{NaCl}$ and $1 \mu \mathrm{l}$ of linear polyacrylamide, mix, add $800 \mu \mathrm{l} \mathrm{100 \%} \mathrm{EtOH}$ and precipitate overnight at $-20^{\circ} \mathrm{C}$.

6. Spin for $30 \mathrm{~min}, 20,000 \times g$ at $4^{\circ} \mathrm{C}$.

7. Aspirate the supernatant.

8. Add $800 \mu \mathrm{l} 80 \% \mathrm{EtOH}$, vortex, spin $5 \mathrm{~min}$ at $4^{\circ} \mathrm{C}$, $20,000 \times g$.

9. Aspirate supernatant, briefly spin again and aspirate any residual liquid, air dry pellet and resuspend in $20 \mu \mathrm{l} 10 \mathrm{mM}$ Tris- $\mathrm{HCl}$ $\mathrm{pH} 8.5$.

10. Optional: quantitate the DNA using the Quant-it ssDNA kit. Since the amount of immunoprecipitated DNA is low, quantitation using a Nanodrop does not work reliable in our hands. Usually, we obtain 100-200 ng of immunoprecipitated library from $4 \mu \mathrm{g}$ of library $(2.5-5 \%)$.

11. Snap freeze the sample in liquid nitrogen and store at $-20^{\circ} \mathrm{C}$. Avoid repeated freeze-thaw cycles.

Enrichment of methylated DNA is monitored after MeDIP and after library amplification by standard qPCR using control primers of known methylated and unmethylated genomic regions (Table 1) using SYBR-green dye (Fig. 3 shows an example). We routinely use $0.5 \mu$ of the MeDIP sample in a $10 \mu \mathrm{l}$ PCR-reaction and perform the reaction. The methylation status of the control regions may differ between cell types and different control regions may be suitable for different cell types due to mosaic methylation patterns. 

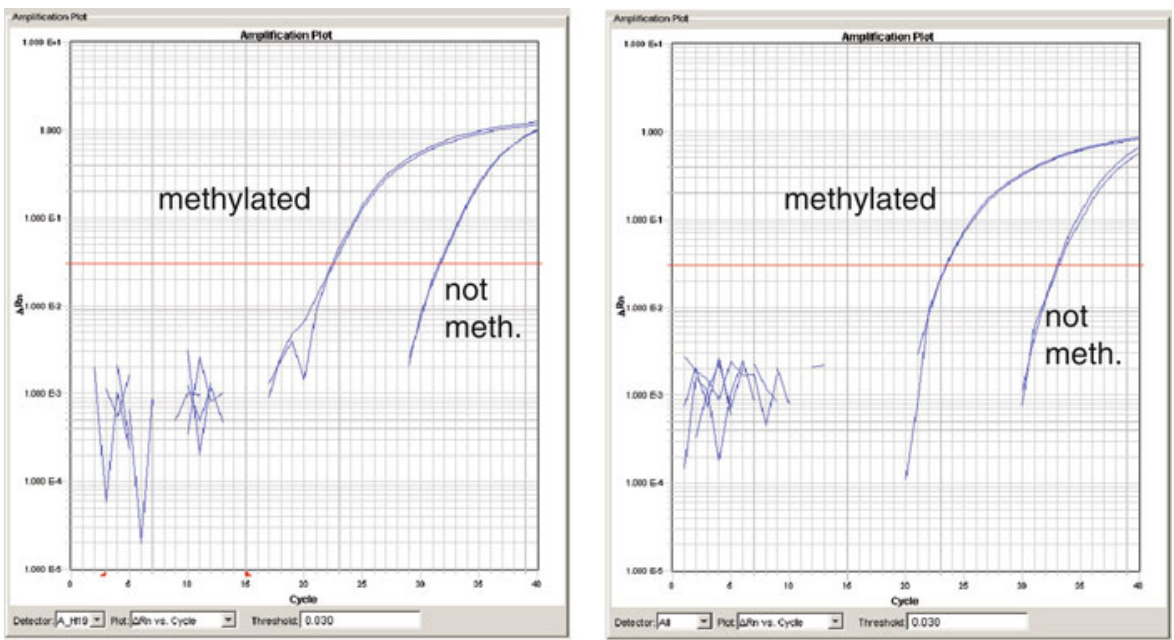

Fig. 3. Enrichment of methylated DNA before (a) and after library amplification (b). Enrichment of the methylated DNA of the same sample was assessed by qPCR using the methylated and unmethylated human genomic control regions listed in Table 1 after MeDIP and before library amplification (a) and after library amplification and size selection (b). Measurements were carried out in duplicate. qPCR amplification plots of an MeDIP from a human ES-cell-DNA sample published in ref. 11 is shown.

\subsection{Amplification of the Library and Size Selection}

The immunoprecipitated DNA is subjected to amplification and size-selection prior to sequencing. If desired, input DNA may also be amplified and size-selected (see Note 10).

1. Set up for one reaction:

\begin{tabular}{|c|c|}
\hline $4 \mu \mathrm{l}$ & $\begin{array}{l}\text { MeDIP-sample ( } 1 / 5 \text { th of the MeDIP-sample or } 40 \mathrm{ng} \\
\text { of input library) }\end{array}$ \\
\hline $15 \mu \mathrm{l}$ & High-Fidelity Phusion polymerase \\
\hline $0.6 \mu \mathrm{l}$ & Primer $1.1(20 \mu \mathrm{M}$, Illumina $)$ \\
\hline $0.6 \mu \mathrm{l}$ & Primer 2.1 ( $20 \mu \mathrm{M}$, Illumina $)$ \\
\hline $9.8 \mu \mathrm{l}$ & $\mathrm{H}_{2} \mathrm{O}$ \\
\hline $30 \mu l$ & Total volume \\
\hline
\end{tabular}

For PCR cycling conditions, use a manual hot-start:

1. $98^{\circ} \mathrm{C}$ for $30 \mathrm{~s}$.

2. $98^{\circ} \mathrm{C}$ for $10 \mathrm{~s}$.

3. $65^{\circ} \mathrm{C}$ for $30 \mathrm{~s}$.

4. $72^{\circ} \mathrm{C}$ for $30 \mathrm{~s}$.

For the amplification, six PCR cycles (repetitions of steps 2-4) are used, thereby keeping the risk of introducing amplification bias low.

Size selection is performed using a $2 \%$ BioRAD $/ 1 \times$ TAE gel. We run the gel for $2 \mathrm{~h}$ at $100 \mathrm{~V}$ and use a $50 \mathrm{bp}$ Marker (NEB). If a better resolution is required, 25 bp DNA ladders may be used. 
The gel chamber is cleaned thoroughly using detergent and water. The gel is loaded as follows: marker, empty well, sample, empty well, marker, empty well, sample, empty well, marker, and so on to avoid cross-contamination of the samples and to ensure a precise size-selection. We excise a 150-400 bp fragment to use for sequencing. Interestingly, the size range of an amplified MeDIPlibrary begins at about $200 \mathrm{bp}$ while the size range of an amplified input library starts at $150 \mathrm{bp}$, indicating a selection for larger fragment sizes by the methylated immunoprecipitation (see Note 5). If desired, the excised gel slices may be frozen in liquid nitrogen and stored at $-20^{\circ} \mathrm{C}$. Purify the DNA using the Qiaquick Gel extraction kit and elute in $30 \mu \mathrm{l}$ (twice with $16 \mu \mathrm{l}$ of $10 \mathrm{mM}$ Tris- $\mathrm{HCl} \mathrm{pH}$ 8.5). Quantify the DNA using a Quant-it dsHSDNA kit. Typically, we obtain 240-300 ng of amplified library. Snap freeze the library and store at $-20^{\circ} \mathrm{C}$ until sequencing. Avoid freeze-thaw cycles.

\section{Notes}

1. Use low-binding DNA tubes for the library preparation and the MeDIP to avoid sticking of the DNA to the tube walls. For the immunoprecipitation and the subsequent washing steps, the use of low-DNA-binding tubes is particularly important in order to reduce nonspecific binding of the DNA to the walls of the tube, which may increase the background signal.

2. Orange G (SIGMA) instead of bromophenol blue is preferred as tracking dye in the gel electrophoresis since Orange $\mathrm{G}$ migrates at about $50 \mathrm{bp}$ and therefore does not interfere with the visualisation of the fragmented DNA.

3. RNAse digest of the DNA is important since the $5 \mathrm{mC}$-antibody will also detect $5 \mathrm{mC}$ in the context of RNA.

4. Shearing conditions need to be adapted to each device. We recommend not to change the shearing device within one experimental series. Also the plastic ware used (thickness of the walls) may influence shearing conditions. Cooling of the DNA during sonication is important since AT-rich regions are less stable to degradation and will be depleted from the sample.

5. Sheared DNAs within one experiment should be of equal size. MeDIP-seq is an enrichment-based method and as such it is dependent on the number of methylated CpGs within one DNA fragment. Longer fragments contain a higher number of CpGs and this will influence the enrichment.

6. Snap freezing of the DNA samples in liquid nitrogen is the best way to preserve the integrity of the sample.

7. We routinely use $4 \mu \mathrm{g}$ of DNA library. If less DNA is used, the amount of antibody and beads needs to be adapted. 
8. Avoid freeze-thaw cycles of the antibody and of your samples.

9. Ice water has a better thermal conduction compared to ice alone. Immediate cooling is important to prevent renaturation of the DNA.

10. In our point of view, sequencing of the input DNA is not generally necessary, although it serves as a control to identify a potential PCR-amplification bias. However, as an enrichmentbased method, MeDIP is affected by copy number variations and especially for cancer samples, this is an important issue. In this case, sequencing of the input samples at a low coverage may be useful to identify regions of copy number variations.

\section{Acknowledgments}

CG and JA are funded by the German Ministry of Education and Research (BMBF) within its National Genome Research Network (01GS08111) and the ERASysBio Plus programme (0315717A). We thank Justyna Jozefczuk for providing genomic DNA of undifferentiated human embryonic stem cells and the corresponding endoderm-differentiated cells used for the qPCR assay in Fig. 3 and Aleksey Soldatov, Tatiana Borodina and Aleksey Kirpy for advice on library preparation. We thank Vardhman Rakyan and Stephan Beck for helpful discussions regarding the MeDIP-seq protocol and for providing the human control primer sequences prior to publication.

\section{References}

1. Lister R, Pelizzola M, Dowen RH et al (2009) Human DNA methylomes at base resolutionshow widespread epigenomic differences. Nature 462:315-322

2. Kriaucionis S, Heintz N (2009) The nuclear DNA base 5-hydroxymethylcytosine is present in Purkinje neurons and the brain. Science 324:929-930

3. Song CX, Szulwach KE, Fu Y et al (2011) Selective chemical labeling reveals the genomewide distribution of 5-hydroxymethylcytosine. Nat Biotechnol 29:68-72

4. Meissner A, Mikkelsen TS, Gu H et al (2008) Genome-scale DNA methylation maps of pluripotent and differentiated cells. Nature 454:766-770

5. Harris RA, Wang T, Coarfa C et al (2010) Comparison of sequencing-based methods to profile DNA methylation and identification of monoallelic epigenetic modifications. Nat Biotechnol 28:1097-1105
6. Serre D, Lee BH, Ting AH et al (2010) MBDisolated genome sequencing provides a highthroughput and comprehensive survey of DNA methylation in the human genome. Nucleic Acids Res 38:391-399

7. Bock $\mathrm{C}$, Tomazou EM, Brinkman $\mathrm{AB}$ et al (2010) Quantitative comparison of genomewide DNAmethylation mapping technologies. Nat Biotechnol 28:1106-1114

8. Down TA, Rakyan VK, Turner DJ et al (2008) A Bayesian deconvolution strategy for immunoprecipitation-based DNA methylome analysis. Nat Biotechnol 26:779-785

9. Ruike Y, Imanaka Y, Sato F et al (2010) Genome-wide analysis of aberrant methylation in human breast cancer cells using methylDNA immunoprecipitation combined with high-throughput sequencing. BMC Genomics 25(11):137

10. Maunakea AK, Nagarajan RP, Bilenky $M$ et al (2010) Conserved role of intragenic DNA 
methylation in regulating alternative promoters. Nature 466:253-257

11. Chavez L, Jozefczuk J, Grimm C et al (2010) Computational analysis of genome-wide DNA methylation during the differentiation of human embryonic stem cells along the endodermal lineage. Genome Res 20:1441-1450

12. Jin SG, Kadam S, Pfeifer GP (2010) Examination of the specificity of DNA methylation profiling techniques towards 5-methylcytosine and 5-hydroxymethylcytosine. Nucleic Acids Res 38:e125

13. Weber M, Davies JJ, Wittig D et al (2005) Chromosome-wide and promoter-specific analyses identify sites of differential DANN methylation in normal and transformed human cells. Nat Genet 37:853-862

14. Butcher LM, Beck S (2010) AutoMeDIP-seq: a high-throughput, whole genome, DNA methylation assay. Methods 52:223-231 